\title{
Constraining depth and architecture of the crystalline basement based on potential field analysis - the westernmost Polish Outer Carpathians
}

\author{
Jan BARMUTA ${ }^{*}$, Mateusz MIKOŁAJCZAK², Krzysztof STARZEC ${ }^{1}$ \\ ${ }^{1}$ AGH - University of Science and Technology, Faculty of Geology, Geophysics and Environmental Protection, al. Mickiewicza 30, 30-059 \\ Kraków,Poland; jbarmuta@agh.edu.pl \\ ${ }^{2}$ Institute of Geological Sciences, Polish Academy of Sciences, ul. Senacka 1, 31-002 Kraków, Poland \\ * Corresponding author
}

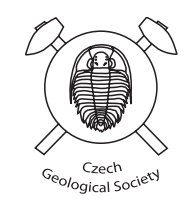

The aim of this work was to establish the structure of a crystalline basement along the previously constructed regional cross-section located in the westernmost part of the Polish Outer Carpathians. The analysis of the gravity and magnetic data, additionally constrained by the borehole information, geological maps and seismic profile was carried out to anticipate the depth to the crystalline basement. Based on the qualitative interpretation, several basement-rooted faults were delineated that in some cases most probably affected the structural evolution of the Carpathians Fold and Thrust Belt. Moreover, along the entire cross-section, the basement seems to be located much deeper than previously anticipated. Lastly, the 2D potential fields modelling indicates that a continuous sedimentary cover, most probably represented by the Devonian and Carboniferous sequence or Miocene sediments of the Carpathian foredeep, may be expected below the Carpathian nappes along the whole cross-section length.

Keywords: Outer Western Carpathians, potential fields, crystalline basement, tectonics

Received: 24 May 2019; accepted: 12 October 2019; handling editor: A. Guy

\section{Introduction}

The Silesian Unit in the westernmost part of the Polish Outer Carpathians Fold and Thrust Belt (OCFTB) exhibits simple, almost homoclinal character. The sedimentary sequence of the Silesian Unit starts with the oldest Vendryně Fm. of the Upper Jurassic-Lower Cretaceous age (formerly the Lower Cieszyn Beds) and ends up with the youngest, Oligocene Krosno Fm. (Burtan 1973). Based on the field observations, a total stratigraphic thickness of this sequence equals to $c .5400 \mathrm{~m}$, of which at least $2500 \mathrm{~m}$ is accounted for by the Godula Fm. alone. However, even more than $3000 \mathrm{~m}$ of the stratigraphic thickness was postulated by Słomka and Słomka (2001) or Picha et al. (2006).

On the other hand, the published maps of the subCarpathian basement show its top at depths no greater than $3000 \mathrm{~m}$ b.s.l. in the southern part of the Silesian Unit (Buła and Habryn 2008) or even 2000 m b.s.l. as stated by Paul et al. (1996b). Assuming no drastic thickness variations within the sedimentary sequence of the Silesian Unit, such estimations of the basement depth are inconsistent with the known thickness of the Silesian Unit. Having this in mind, the rationale behind our work was to resolve this inconsistency and verify the actual depth and structure of the sub-Carpathian basement along a regional cross-section (Figs 1 and 2). In order to achieve this goal, a joint 2D quantitative interpretation of gravity and magnetic data was performed along this regional cross-section. The interpretation was supported by the qualitative analysis of magnetic and gravity maps and their derivatives to recognize structural features in the sub-Carpathian basement.

Validation of geological cross-sections through a 2D forward gravity and magnetic modelling is a well-established method of de-risking used in subsurface prospecting and exploration (e.g. Kadima et al. 2011; Nemčok et al. 2013; Rippington et al. 2015). The principal challenge within this method is, among others, in distinguishing the source of the gravity and magnetic anomalies, and whether they relate to superposed geological bodies or a single body mappable over a large area (Rippington et al. 2015).

In the western part of the OCFTB, the basement comprises part of the Brunovistulicum Terrane (e.g.: Buła and Żaba 2008; Żelaźniewicz et al. 2011; Buła et al. 2014). The sub-Carpathian geology of the Polish part of the Brunovistulicum was extensively elaborated on mainly by Buła, Żaba and Habryn (e.g.: Buła and Żaba 2008; Buła and Habryn 2008 and references therein). Because of great depths, the basement structure was investigated mainly by geophysical, usually non-seismic, methods (e.g.: Bojdys and Lemberger 1986; Ryłko and Tomaś 1995; Królikowski and Młynarski 2003; Stefaniuk 2006; Grabowska et al. 2007; Stefaniuk et al. 2007; Bojdys et al. 2008), however, some deep boreholes, such as Bystra- 
IG1, managed to reach it even in the more central part of the OCFTB (Żytko 1978).

In publications of Grabowska et al. (2007) only few magnetic anomalies were identified in the entire research area and its immediate vicinity. In the eastern part, a significant magnetic high (the Jordanów anomaly), related to a deep basement, is reported, while to the north, in the area of Andrychów, Bielsko-Biała and Czechowice, a group
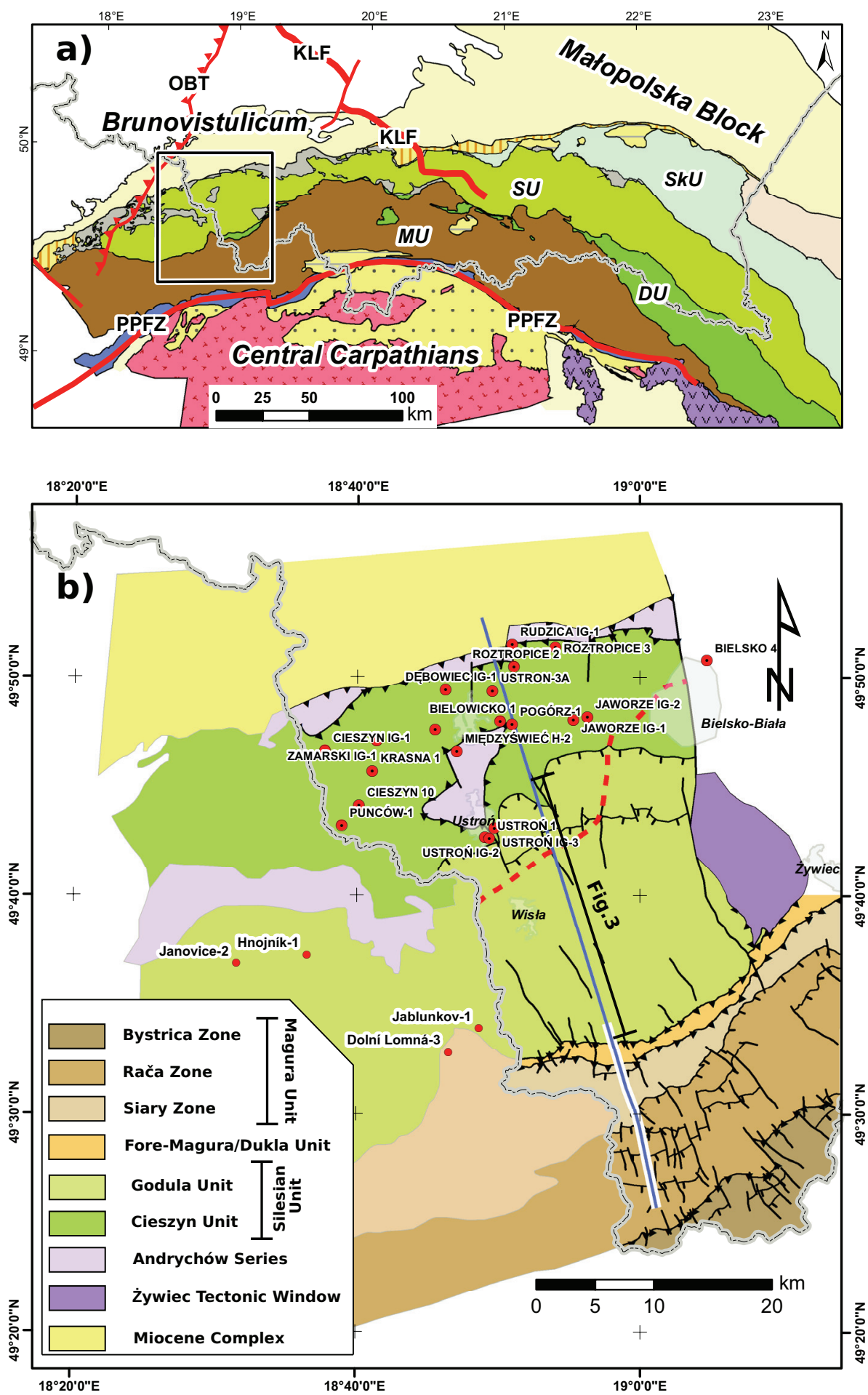

of smaller positive anomalies was identified. The origin of these anomalies is linked to the mafic rock intrusions (teschenites) found in the northernmost part of the Silesian Nappe, as well as to an elevated crystalline basement in the Andrychów area. The gravity map (a Bouguer anomaly map) reflects rather simple structure; however, the residual anomalies clearly indicate an anomalous zone related to the Żywiec tectonic window and the Andrychów zone.

A remarkable analysis of the structure of the basement in the eastern part of the Czech Republic was delivered by Gnojek and Hubatka (2001). Based on geophysical and borehole data, the authors not only created a detailed structural map of the basement, but also provided a geological interpretation of anomalies visible on the magnetic maps. Because of the close vicinity and geological similarity, it is believed that those results may also represent the character of the basement structure in the current study area.

In the paper by Gnojek and Hubatka (2001), two magnetic highs were distinguished, both of which exhibit a roughly latitudinal trend. The northern and the southern magnetic highs, named the Silesian Regional Anomaly (SIL) and the South Moravian-Beskydy Anomaly (SMB), respectively, are separated by a magnetic-low zone. This is interpreted as two basement blocks divided by a suture zone of Cadomian age. Those anomalies continue into the Polish territory; however, the magnetic

Fig. 1 Simplified geological map of the research area. Inset (a) MU Magura Unit, DU - Dukla Unit, SU - Silesian Unit, SkU - Skole Unit, PPFZ - Peri-Pieniny Fault Zone, OBT - Orłowa-Boguszowice Thrust, KLF Kraków-Lubliniec Fault. The black rectangle indicates research area (enlarged). b - The red dashed line marks southern extent of the Paleozoic sedimentary cover according to Buła and Habryn (2008), blue line indicates the location of the Carpathica 2018 regional crosssection with the extent of the seismic data marked with white envelope. 


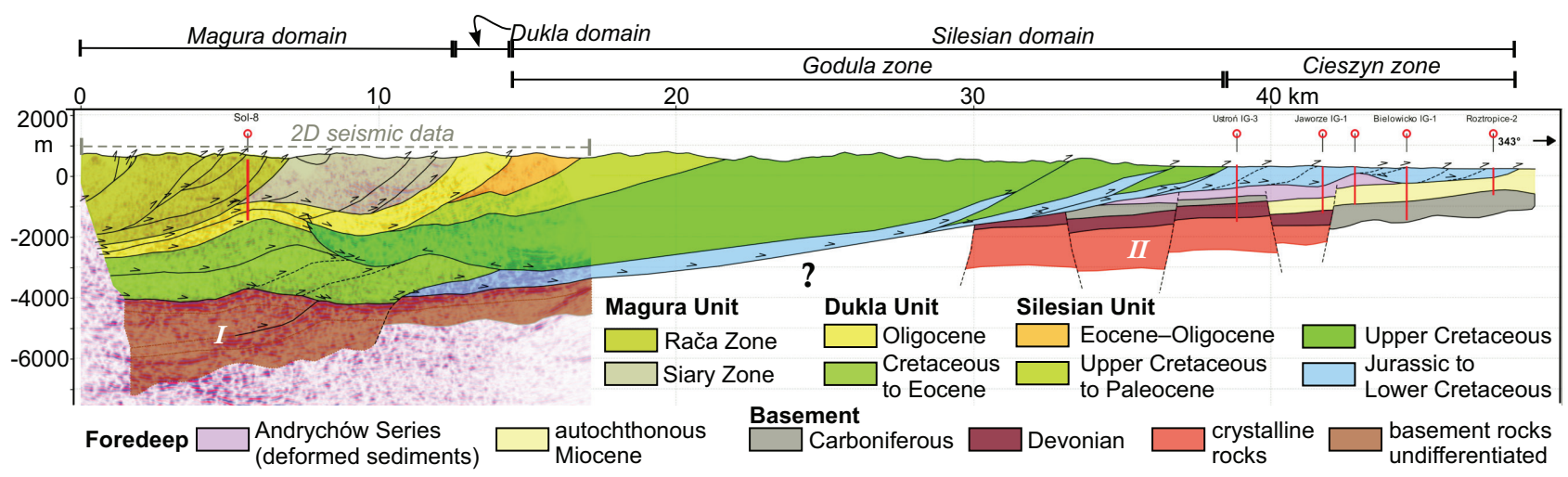

Fig. 2 Regional cross-section after Starzec et al. (2017), slightly modified. I - anticipated Paleozoic sediments based on seismic reflections pattern, II - horst-and-graben-like structures in the Carpathian basement interpreted based on well data and geological maps, ? - "no data zone" - unknown structure of the Carpathian basement.

low zone (i.e. the stipulated suture) narrows significantly. The SMB anomaly is composed of several small-scale anomalous zones, one of which, the Beskydy Anomaly (BES), lies close to the southern part of the research area.

\section{Geological setting}

The Outer Carpathians Fold and Thrust Belt is an arcuate orogen extending for more than $1300 \mathrm{~km}$ from Austria to Romania. Its origin is related to rifting of the European Platform followed by the collision of several microplates (e.g.: Golonka et al. 2006). The Outer Carpathians possess a fold and thrust belt architecture, where the thinskinned tectonics style predominates; however, some authors indicated the possibility of basement shortening during the compression episode (e.g.: Ślączka et al. 2006). The OCFTB is composed of several tectonic units, often referred to as nappes, each exhibiting a unique sedimentary sequence that corresponds to a specific basin. The units were unrooted and thrust onto their foreland.

In the structure of the westernmost part of the OCFTB, the following units can be distinguished (from south to north) (Figs 1 and 2): (1) the Magura Unit which is composed of several second-order units or zones, (2) the Fore-Magura Unit forming a narrow belt in its front, (3) the Silesian Unit with a complete lithostratigraphic profile exposed on the surface and (4) the Andrychów Unit or series, formerly regarded as the Sub-Silesian Unit, and currently as a unit composed of folded Miocene deposits that can be related to the Zgłobice Unit in central and eastern part of the Polish Carpathians (Wójcik et al. 1999; Wójcik and Nescieruk 2000).

\subsection{Magura Unit}

The Magura Unit is located in the most central part of the OCFTB and is traditionally subdivided into the following second-order subunits or zones (from the south to the north): the Krynica, Bystrica, Rača and Siary subunits (e.g. Koszarski et al. 1974; Oszczypko 1992). Numerous authors suggested rather flat and shallow morphology of the basal thrust of the Magura Nappe that is overthrust above the tectonically lower units (e.g. Żytko et al. 1989; Nemčok et al. 2006). Previous interpretations of the subsurface structure of the western part of the Carpathians assumed the continuation of the Fore-Magura and Silesian units below the Magura Unit, which implied also a significant thinning of the sedimentary sequence of the Silesian Unit (e.g. Ryłko and Żytko 1980; Żytko et al. 1989; Paul et al. 1996a, b; Oszczypko 2004; Golonka 2007b; Golonka et al. 2011; Górecki 2011). However, based on new seismic data it was suggested that the Silesian Unit terminates abruptly just below the front of the Magura and Fore-Magura units, while beneath the Magura Unit cover, series of duplexes formed within the Fore-Magura succession (an equivalent of the Dukla Unit) is present (Starzec et al. 2017) (Figs 1-2).

Within the research area, the Magura Unit is represented by the Bystrica, Rača and Siary zones, which differ from each other in both sedimentary succession and structural style (e.g. Sikora and Żytko 1960; Ryłko et al. 1992; Starzec et al. 2014). In general, the oldest sediments recorded in this part of the Magura Unit belong to the Upper Cretaceous Malinowa Shale Fm. (Sikora and Żytko 1960; Oszczypko et al. 1990). It is followed by a thick sequence of turbiditic sandstones and shales that formerly was included into one lithostratigraphic division, named Inoceramian Beds (e.g. Książkiewicz 1974), and later separated into the Jaworzynka Fm. with the Mutne Sandstone Member occurring in the northern Siary zone and the Ropianka and Szczawina formations in the southern zones (e.g. Sikora and Żytko 1960; Oszczypko 1992; Cieszkowski et al. 2007). These formations represent the Upper Cretaceous-Paleocene time span (e.g. Malata et al. 1996; Oszczypko et al. 2005). At the transition time from the Paleocene to Eocene, the sedimentation of the variegated shales started in the 
whole Magura Basin, forming the Labowa Shale Fm. (Oszczypko et al. 2005). Subsequently, during the middle Eocene, in the southern zones, shales were replaced by thin-bedded sandstone-shale facies of the Beloveza Fm. (Oszczypko et al. 2005; Golonka and Waśkowska 2012). In the northern part of the Rača zone this formation contains also thick-bedded sandstone body distinguished as the Pasierbiec Member (e.g. Ryłko et al. 1992; Golonka and Waśkowska 2012). The youngest deposits, but also the thickest within the Magura Unit succession, are represented by the Magura Fm. in the southern zones and the Zembrzyce Beds in the Siary zone (e.g. Książkiewicz 1966; Oszczypko et al. 2005).

According to the surface data, the present architecture of the Magura Unit comprise thrusts or slices of variable scale accompanied by thrust-related folds. Numerous north-south trending (perpendicular to thrusts), normal or transtensional faults are also present (Fig. 1).

\subsection{Silesian Unit}

The lithostratigraphy of the Silesian Unit includes a continuous sequence starting from the Vendryně Fm. (previously known as the Lower Cieszyn Beds) of the uppermost Jurassic-lowermost Cretaceous age up to the Oligocene Krosno Fm. Traditionally, the Silesian Unit in the study area is subdivided into two subunits, i.e. the Godula and Cieszyn units (Paul et al. 1996a) (Fig. 1). The Cieszyn Unit consists mainly of the Vendryně Fm. covered by the Cieszyn Limestone Fm., Hradiště (Grodziszcze), Veřovice and Lhoty formations of the Jurassic to lower Cretaceous age. The bulk of the Godula Unit comprises the Godula and Istebna beds of the Upper Cretaceous-Paleocene age that are most probably underlain by the above-listed Jurassic-Lower Cretaceous formations known from the Cieszyn Unit. The youngest deposits of the Godula Unit are represented by the Eocene Hieroglyphic Fm. with the Ciężkowice Sandstones covered by the Oligocene Menilite and Krosno formations, which document the last stage of the Silesian Basin evolution. Unlike the Magura Unit, the Silesian Unit exhibits a simple homoclinal structure dipping to the south at $c .20^{\circ}$ with some minor thrusts located in its northern part (Starzec et al. 2017).

The basement of the Polish OCFTB is composed of two tectonic units, also referred to as terranes (Fig. 1). The eastern unit, i.e. the Małopolska Terrane (Żelaźniewicz et al. 2011), formed a part of the Baltica realm since the Late Neoproterozoic times (e.g.: Nawrocki and Poprawa 2006), and its geotectonic history was similar to that of the Baltica Craton. The western unit, named the Brunovistulicum Terrane (Żelaźniewicz et al. 2011), exhibits a different and not so unambiguous Paleozoic evolution. During the disintegration of the Pannotia Continent, the Brunovistulicum was most prob- ably located close to the Avalonian part of the Gondwana Continent. However, different positions and wonderpaths of this unit during the early Paleozoic times were also proposed (e.g., Moczydłowska 1997; Cocks 2002; Malinowski et al. 2005; Nawrocki et al. 2004; Cocks and Torsvik 2005; Stampfli and Kozur 2006; Kalvoda et al. 2008). During the opening of the Rheic Ocean, the Brunovistulicum most probably drifted northward as a part of the Eastern Avalonia microcontinent (e.g.: Golonka 2007a; Golonka et al. 2009a; Gawęda and Golonka 2011). From the Middle Devonian to the Late Carboniferous the Brunovistulicum was covered by a sedimentary sequence. The Devonian sediments are dominated by carbonates related to extension-dominated epicontinental basin, which continued into the earliest Carboniferous (Narkiewicz 2007). During the late Viséan, the Brunovistulicum underwent a significant tectonic subsidence in response to the formation of the Variscan Orogen. A few kilometer thick sequence of a culm facies, i.e. syn-orogenic, terrigenous sediments, was deposited during these times (Narkiewicz 2007). In the Late Carboniferous period, the eastern part of the Brunovistulicum (the Upper Silesian Basin) was covered by a post-orogenic molasse with abundant coal layers (e.g. Kotas 1994). The Paleozoic sediments or crystalline basement rocks are covered directly by the Miocene sediments of the Carpathian foredeep (Buła and Habryn 2008).

Despite that the basement in the westernmost part of the Polish OCFTB lies shallower than its eastern part, it is still not well explored. Current geological investigations carried out in Poland and summarized by Buła and Żaba (2008) and Buła et al. (2014) indicated a complex structure of the Polish part of the Brunovistulicum composed of metamorphosed Ediacaran sediments of flysch affinity, as well as of crystalline rocks of various origin and age ranging from the Archean to Early Paleozoic, often with Variscan metamorphic overprint. Within the research area and in its vicinity, the results of deep exploration drilling in Poland and in the Czech Republic, supported by geophysical investigations, allowed to distinguish two separate zones composed of both mafic and felsic rocks, i.e. the Jablunkov Massif and the Andrychów Massif, respectively (Gnojek and Hubatka 2001; Picha et al. 2006; Buła and Żaba 2008). The Jablunkov Massif is built of gabbros and gabbronorites while the Andrychów Massif is composed of silica-rich metamorphic rocks.

\section{Constraining the structure of the OCFTB along the regional cross-section - data and methods}

A regional geological cross-section, for simplicity referred to as the Carpathica 2018, was developed by 
Starzec et al. (2017) in the framework of the Blue Gas II-ShaleCarp Project and refined during further research. It was constructed using various data, described below, that allowed to reliably determine the structure of the Carpathian Fold and Thrust Belt, while the information about the sub-Carpathian units was only poorly represented.

\subsection{Well data}

Numerous wells provide information regarding the sedimentary cover and the crystalline basement in the research area (Fig. 1). In the northernmost part of the Carpathica 2018 cross-section, the Precambrian rocks were reached by Ustron C-1, Ustroń IG-2, Ustroń IG3 and Ustroń U-3A wells; moreover, all these wells encountered also the Devonian and Lower Carboniferous strata above the crystalline basement. To the east, Łodygowice-IG1 and Bystra-IG1 wells encountered the basement metamorphic rocks directly below the Carpathian sedimentary cover or below a relatively thin layer of brecciated rocks regarded as the Miocene deposits (Żytko 1978). In the southern part Sól-8 well reached $2000 \mathrm{~m}$ MD (measured depth), but only the Magura Unit was intercepted. To the west, in the Czech Republic, four deep wells were located in the close vicinity of the Polish border (Picha et al. 2006). Except for Dolní Lomná-3 well, the Carboniferous and Devonian sediments were found in all other wells. In Jablunkov-1 and Dolní Lomná-3 wells, diorites and metamorphic rocks were drilled, respectively. The stratigraphic profiles for the Polish wells were derived from the Central Geological Database (CBDG) (http://geologia.pgi.gov.pl) and from the Explanations to the Detailed Geological Maps of Poland (Wójcik and Nescieruk 2000; Nescieruk and Wójcik 2001a, b), while the paper of Picha et al. (2006) was used for the Czech wells.

\subsection{Geological maps}

For the southern part of the research area occupied by the Magura and Dukla units, a new geological map was compiled with numerous dip measurements available in a digital form (Starzec et al. 2014). The northern part, occupied by the Silesian Unit, is covered by the publicdomain "Skoczów" and "Wisła" sheets of the Detailed Geological Map of Poland 1:50,000 (Burtan 1973; Nescieruk and Wójcik 2001a, b). All structural features and dip measurements were digitized along the crosssection and its immediate surroundings. For a major part

a

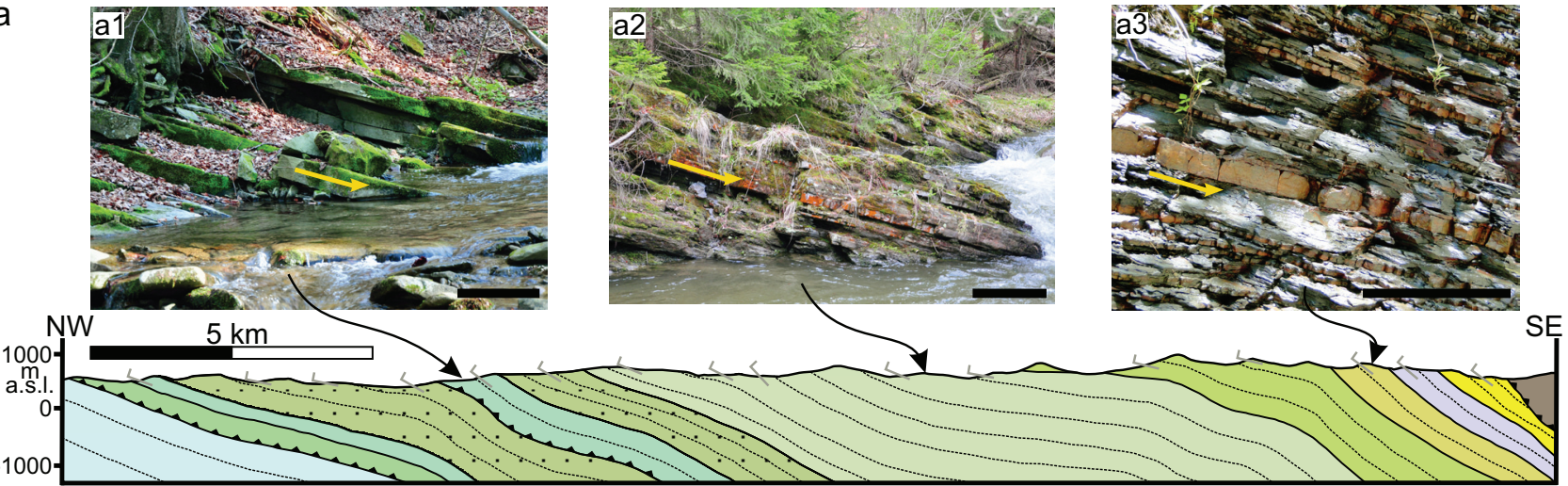

Veřovice, Hradiště and Vendryně formations Lhoty Fm.

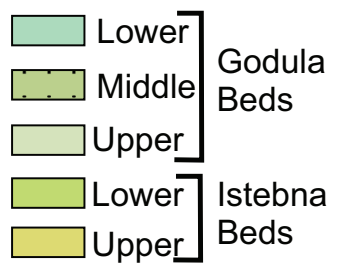

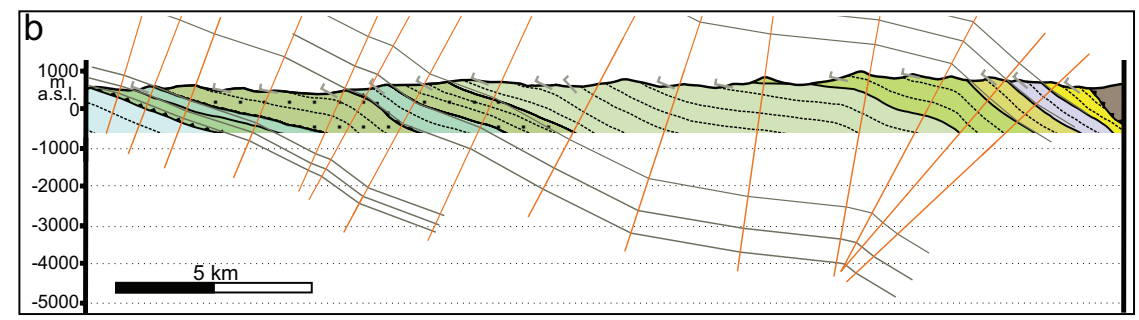

$\checkmark$ Hieroglyphic Beds

Menilite and Krosno Beds

Dukla Unit

Fig. 3 Cross-section showing the subsurface structure of the Godula Subunit: a - Cross-section extrapolated from the surface data, an outcrop-scale homoclinal structure of different parts of the subunit is shown in the photos: (a1) sequence of thin- to thick-bedded sandstones typical of the Lower Godula Beds, (a2) sequence of mainly thin- and medium-bedded sandstone-shale interbeddings characteristic of the Upper Godula Beds, (a3) thinbedded black shales intercalated with sandstones and siderites typical of shaly interval of the Upper Istebna Beds. Arrows indicate dip direction, scale bar equals $0.5 \mathrm{~m}$; b-Geometry of strata approximated with the use of the Move Software by projection from dip data with the kink-band method. 
of the Silesian Unit, the strike and dip measurements and outlines of the lithostratigraphic units were the only available structural data used for geological cross-section preparation. However, due to its simple, homoclinal character, it was possible to reliably reproduce the structure of this unit using a kink-band method.

\subsection{Seismic data}

The structure of the Carpathian units in the southern part of the cross-section was resolved based on the surface geology as well as on the 2D seismic data (Figs 2-4). The designed acquisition array anticipated a 40 meter offset

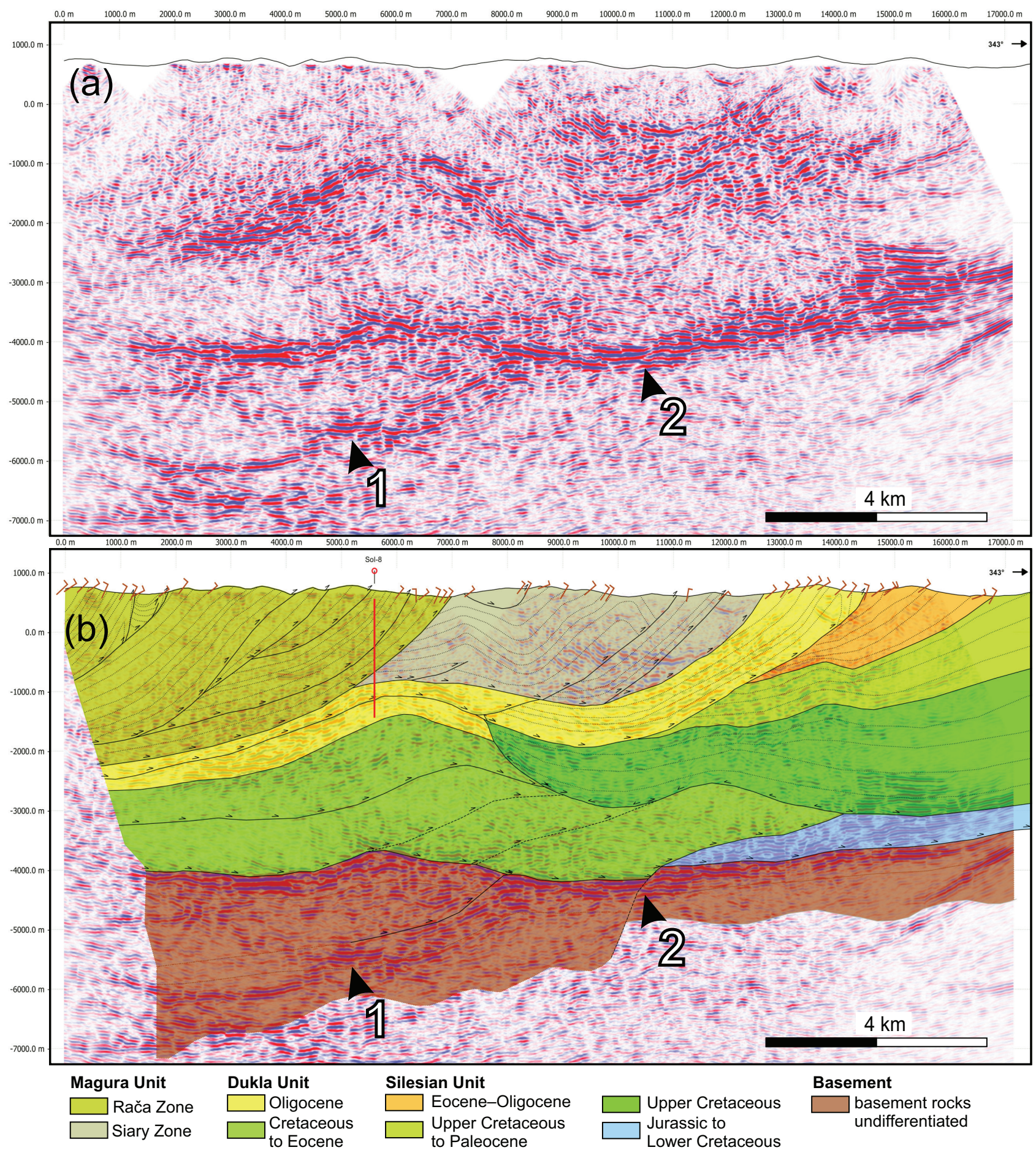

Fig. 4 Uninterpreted (a) and interpreted (b) seismic profile. Arrows point to the (1) assumed thrust within the Devonian and Carboniferous sequence and (2) seismic horizon linked with the base of the Carpathian units. 
between the shotpoints and a 20 meters spacing between the receivers. However, due to difficult terrain conditions, the resultant acquisition geometry was highly irregular with numerous shot points missed, which significantly reduced the effectiveness of processing procedures. An explosive type of source was used to induce an acoustic wave. One of the main problems encountered during the seismic data processing step was the low signal to noise ratio and strong refraction and surface waves effects masking the useful signal. The processing was carried out in three steps: the Post-Stack Time Migration (PostSTM), Pre-Stack Time Migration (PreSTM) and Pre-Stack Depth Migration (PreSDM). Results of the processing were verified and guided by a preliminary interpretation. The PreSDM version, considered as the most reliable, was chosen for the final interpretation. The interpretation process was performed in a "top-to-bottom" manner, where the shallow structure, poorly imaged on the seismic data, was constrained by a limited borehole information (e.g.: Sól-8 well), geological maps and dip measurements and thereafter linked up with seismic horizons visible in the deeper part of the seismic profile. This approach allowed also to tentatively identify the lithostratigraphic units on the seismic profile, as the available borehole data were sparse and incomplete, thus making a classic seismic-towell tie analysis impossible.

\section{The structure of the OCFTB along the Carpathica 2018 cross-section}

In the northern segment of the cross-section, the subCarpathian sedimentary complex as well as the crystalline basement are well constrained by the borehole data (Figs 1-2). More than twenty boreholes located within the Cieszyn Subunit area (Fig. 1) reached the Carpathian sole thrust. They reveal that the thickness of the Carpathian sedimentary cover in this area is relatively low but highly variable. It ranges from c. $200 \mathrm{~m}$ to almost $700 \mathrm{~m}$, being significantly lower only in the northernmost marginal zone of the Cieszyn Subunit. No clear trend of the sedimentary cover thickening toward the central part of this subunit or along its strike can be inferred from the borehole data alone. Some boreholes located within the middle part of the Cieszyn Subunit (e.g. Pogórz 2 and 7) show even thicker interval of the Carpathian units' cover than the ones located in its southernmost part (e.g. Ustron IG-2 and IG-3). Specifically, $629 \mathrm{~m}$ and $695 \mathrm{~m}$ of the Upper Jurassic to Lower Cretaceous deposits were recorded in the two Pogórz boreholes, whereas $600 \mathrm{~m}$ and $523 \mathrm{~m}$ were observed in the southern ones. On the other hand, there are instances in which closely spaced boreholes display significant differences in thickness of the Carpathian sedimentary cover, e.g. $232 \mathrm{~m}$ in Pogórz 1 and $629 \mathrm{~m}$ in Pogórz 2 (Fig. 2). Such differences are most probably related to geometry of the basement that is formed here by the Brunovistulicum Terrane. According to Kotas (1994), the south-eastern part of the Brunovistulicum is cut mostly by normal faults dividing it into latitudinal orientated horsts and grabens.

Between the basal thrust of the Cieszyn Subunit and the basement, a sequence of Miocene deposits is present. Within this sequence, the upper part is usually regarded as an olistostrome, known as the Andrychów series, while the lower part represents the autochthonous molasse of the Carpathian Foredeep of the middle Miocene age. The thickness of the top part reaches up to $400 \mathrm{~m}$ in the north (i.e. Pogórz 1) and slightly exceeds $500 \mathrm{~m}$ in the southern part of the Cieszyn Subunit (Ustron IG-3). On the other hand, the thickness of the autochthonous Miocene deposits decreases to the south from c. 500-600 $\mathrm{m}$ at the margins of the Cieszyn Subunit to c. $300 \mathrm{~m}$ in its middle part (e.g. Ogrodzona 1 and Międzyświeć $\mathrm{H}-2$ boreholes). The Miocene sediments disappear at a distance of c. 12-13 km south of this subunit thrust (Moryc 2005), thus Ustron IG-2 and IG-3 boreholes drilled only through the Andrychów series, and then entered directly the basement rocks (Fig. 2). As stated by Moryc (2005), the horst and graben structure of the basement controls the thickness of the Miocene sediments.

The top part of the basement is built of almost horizontal deposits representing the Devonian and Carboniferous sedimentary cover of the Brunovistulicum Terrane. Deposits of the first period are represented by dolomites and limestones, subordinately interbedded with mudstones. The whole complex is densely fractured. The Devonian sediments are overlain by the Lower Carboniferous clastic deposits of the Culm facies, mostly sandstones and mudstones alternating with conglomerates. These deposits represent the uppermost part of the basement sedimentary cover present below the southern part of the Cieszyn Subunit. To the north, the Lower Carboniferous sequence is covered by the Upper Carboniferous clastic sediments with abundant coal seams. The whole Devonian and Carboniferous sequence reaches almost $700 \mathrm{~m}$ in thickness (Ustron IG-3 borehole).

Within the studied part of the Cieszyn Subunit the crystalline rocks of the basement are known only from four boreholes, i.e. Roztropice 1, Ustroń IG-3, Krasna 1 and Puńców 1 (Fig. 1). In all of them the basement is built of metamorphic rocks, mostly biotite and migmatite gneisses, crystalline schists and diabases (Konior and Tokarski 1959; Heflik and Konior 1974; Heflik and Moryc 1996). The structural pattern of the crystalline basement surface shows a maximum elevation in the area of Kęty-Bielsko Biała, where it reaches depths of $1500 \mathrm{~m}$ b.s.l. According to Moryc and Heflik (1998), the basement elevation decreases to the north, south and east, 
whereas to the west it remains at constant depths, which is suggested by Bystrice 2 borehole on the Czech side of the Carpathians. Therefore, the discussed area of the Cieszyn Subunit is situated at the northern slope of this basement elevation.

The more central parts of the Silesian Unit, belonging to the Godula Subunit, lack any subsurface control. No boreholes, nor seismic data are available for this area. The structure of this subunit can only be extrapolated from the surface data. The well exposed Upper Cretaceous to Oligocene sedimentary sequence of this subunit. It reveals a rather simple, homoclinal structure; still, a repetition of the lowermost interval evidences the presence of at least two thrust sheets within this subunit (Fig. 3a). The stratigraphic thickness of the sequence is estimated at $c$. 4500-5000 m. Assuming a constant layer thickness, an extrapolation of the surface data yields an excessive thickness of the Godula Subunit in relation to the postulated depth of the basement in this area (Buła and Habryn 2008; Paul et al. 1996b). A space significantly exceeding 5,000 $\mathrm{m}$ would be needed in order to accommodate the entire sequence of the Godula Subunit (Fig. 3b).

The internal structure of the Carpathian units, as well as depth to the basement in the southern part of the cross section, were resolved based on the interpretation of the seismic data (Figs 2 and 4). The Magura and ForeMagura units crop out at the surface along the seismic profile. The main thrust of the Magura Unit exhibits a rather flat geometry; however, its shape is affected by an anticlinal stack formed within the underlying Dukla Unit. The thickness of the Magura Unit reaches $c .3000 \mathrm{~m}$. In the northern part of the seismic section the pinching-out sedimentary sequence of the Silesian Unit is present. A pronounced seismic reflection is observed at $c .4000 \mathrm{~m}$ b.s.l. Due to the lack of well control, it was impossible to correlate it with any specific geological horizon. Nevertheless, it indisputably represents the base of the Carpathian units. Based on the similarity to the seismic signal characteristics observed on a seismic section in the Andychów-Lachowice area (Golonka et al. 2009b), as well as the results of the wells drilled in the Czech Republic (see above), it was assumed that this horizon could represent the top of the Devonian-Carboniferous sequence. Our interpretation proved that thin-skinned tectonics prevailed in this area but indicators of basementinvolving tectonics are also visible (Figs 2, 4).

\section{Potential fields data analysis}

\subsection{Data origin and description}

The gravity and magnetic data were provided in a digital format by the National Geological Archives of the Polish
Geological Institute - National Research Institute. The gravity data provided by the Polish Geological Institute represent the Bouguer anomaly. The international gravimetric standard IGSN71 datum was used, while the theoretical gravity was based on the GRS80 (Geodetic Reference System '80) reference ellipsoid. The Free Air Gravity data were enhanced by a complete Bouguer reduction for an infinite horizontal slab with density of $2.67 \mathrm{~g} / \mathrm{cm}^{3}$ using a digital elevation model (DEM) from Shuttle Radar Topography Mission 30 Plus (SRTM30Plus). The gravity data set employed in this study consists of gravity measurements derived from over 17000 ground stations completed between 1972 and 1983 during numerous projects. The measurement points cover the study area regularly, with an average of 5.5 points per square kilometer. The gravity data were gridded at a $500 \mathrm{~m}$ interval using a minimum curvature algorithm. The total magnetic intensity (TMI) grid was compiled from the ground and airborne surveys conducted between 1945 and 2004. The magnetic data were gridded at a $500 \mathrm{~m}$ interval and upward continued to $500 \mathrm{~m}$ mean terrain clearance (Fig. 5). The reduction-to-pole (RTP) transform was applied to the magnetic data. It attempts to simplify the magnetic field by rotating the magnetic vector to be vertical, thereby centering all magnetic anomalies above their causative bodies (MacLeod et al. 1993). In other words, after the RTP transform, the TMI can be regarded as measured at the north magnetic pole.

\subsection{Data enhancements}

Total horizontal derivatives (THD) were used to enhance specific signatures of gravity and magnetic fields and associate them with the corresponding geological structures (Figs 5-6). These were calculated using a combination of two software packages: the Geosoft Oasis Montaj ${ }^{\text {TM }}$ and Getech's non-commercial software (GETGrid). The THD shows distinct linear trends along locations of faults that juxtapose blocks of contrasting density (Grauch and Cordell 1987). Consequently, it is a powerful tool for mapping fault trends that may have placed sedimentary rocks against the crystalline basement.

Quantitative modelling for this study was carried out along the Carpathica 2018 cross-section using the Geosoft GMSYS 2D forward modelling package with model layers of infinite length. This modelling technique enabled the conversion of seismically interpreted horizons into the geological bodies present within the model. Each of these bodies appeared as a polygon with a density and magnetic susceptibility assigned. The software forward-calculated the gravity and magnetic response of the model, using the techniques outlined in Talwani et al (1959) and Talwani and Ewing (1960) for the gravity and Talwani and Heirtzler (1964) and Talwani (1965) for 

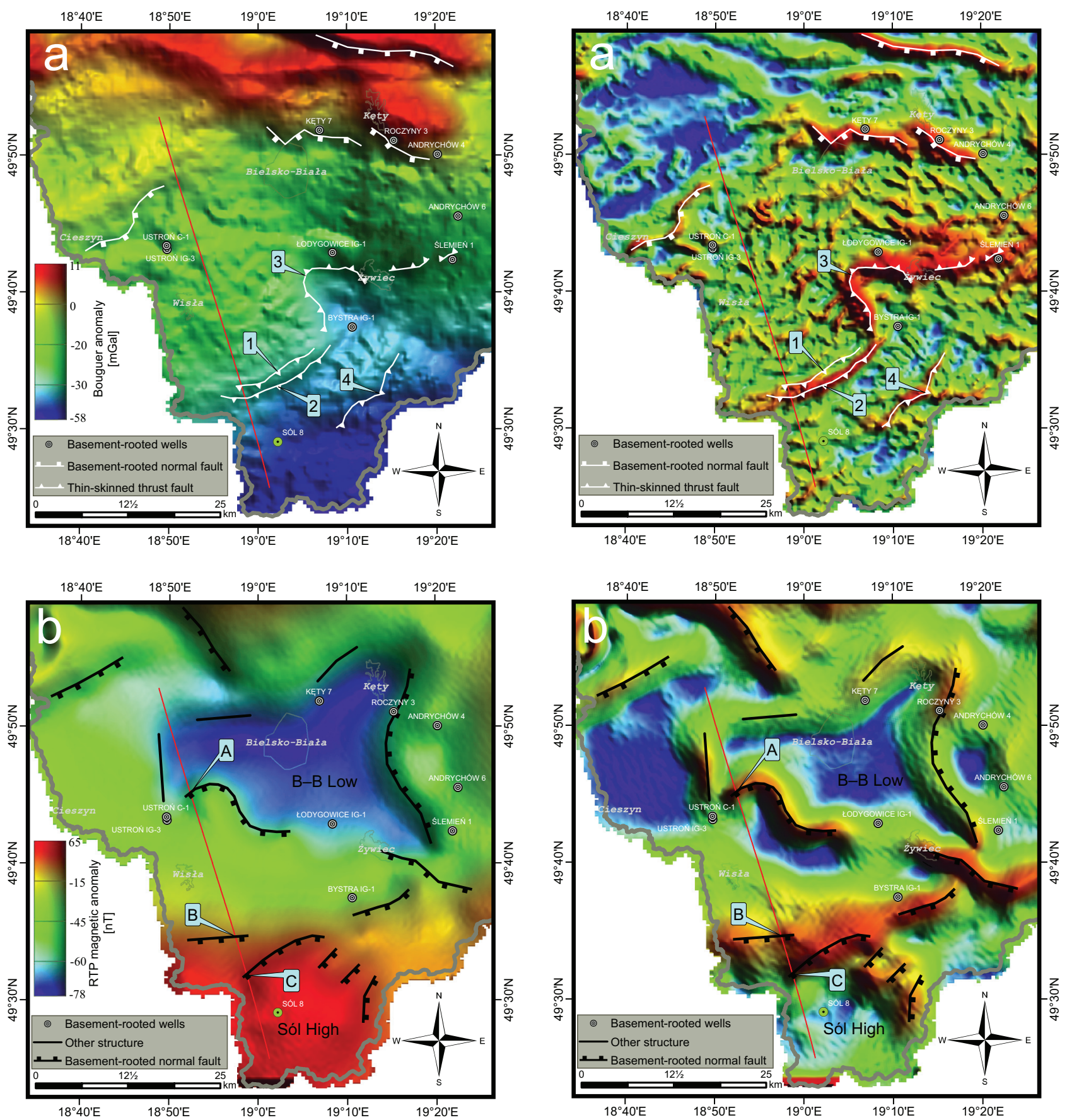

Fig. 5 Key basement-rooted structural elements of the study area overlain on: a-Complete Bouguer anomaly map filtered with a $2 \mathrm{~km}$ low-pass filter; $\mathbf{b}$ - Reduced-to-Pole magnetic anomaly map filtered with a $2 \mathrm{~km}$ low-pass filter. The coordinate system used for presentation of potential fields maps is Poland 1992 that is based on the ETRS89 datum, GRS80 spheroid and the Transverse Mercator projection with $19^{\circ} \mathrm{E}$ as a central meridian. Red line and green circle represent the Carpathica 2018 cross-section and a borehole that did not reach the basement, respectively. B-B Low in (b) means Bielsko-Biała Low.

the magnetics. The model was then interactively adjusted until a satisfactory fit between the synthetic response and the observed gravity and magnetic profiles was obtained.

Fig. 6 Qualitative interpretation of gravity data. Structural elements overlain on: a - Total horizontal derivative of the Bouguer gravity and $\mathbf{b}$ - Total horizontal derivative of the RTP magnetics. Both filtered with a $2 \mathrm{~km}$ low-pass filter. B-B low stands for the Bielsko-Biała Low.

Gravity and magnetic models are non-unique; this means that there is a multitude of density and susceptibility configurations that can produce an anomaly of the same amplitude and wavelength. However, the plausibly resolved structure of the Carpathian units along the cross section, along with the density measurements from wells (Grabowska et al. 2007; Bojdys et al. 2008) and the re- 


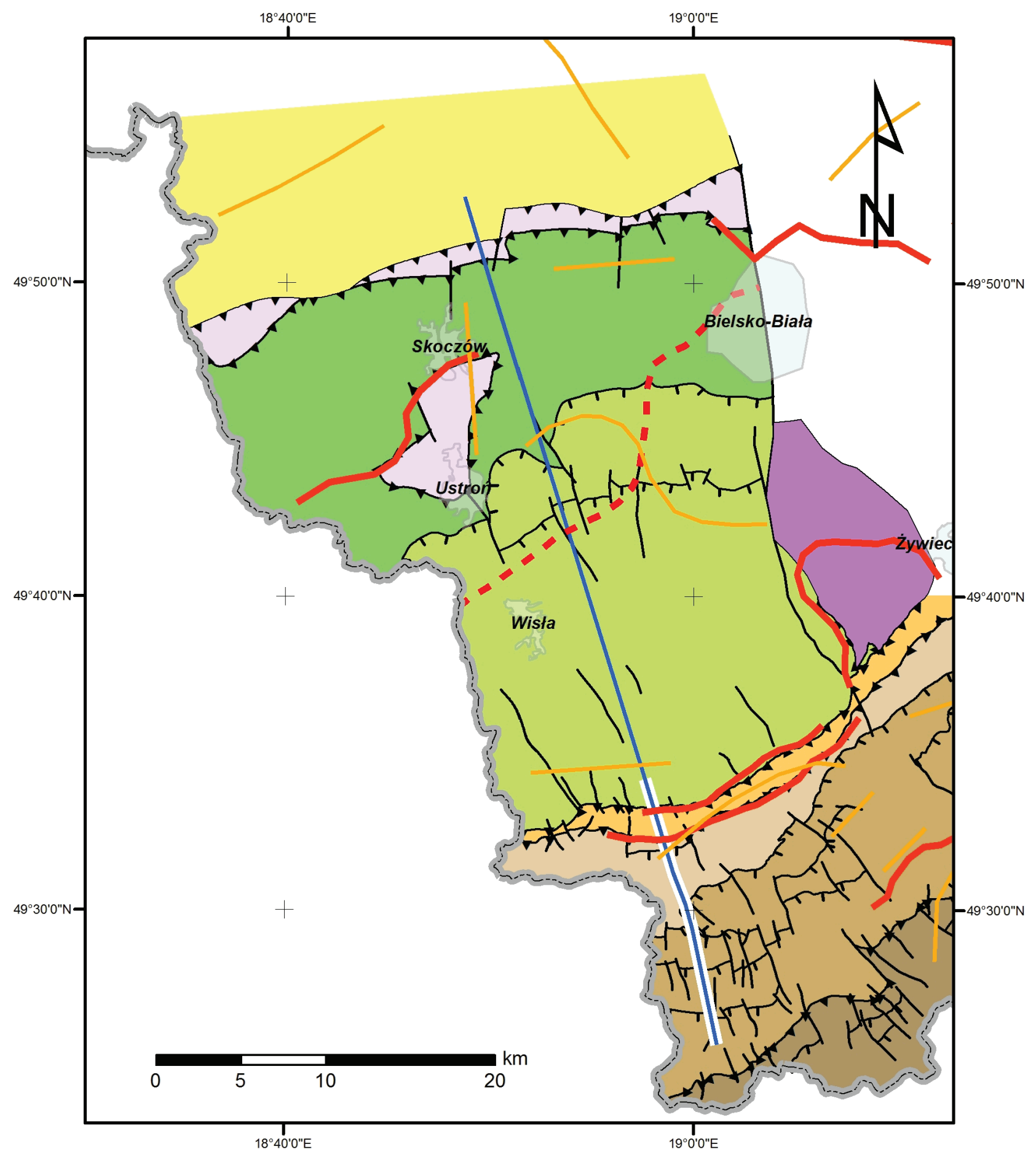

Fig. 7 Simplified geological map of the research area with gravity (solid red lines) and magnetic (solid orange lines) lineaments juxtaposed. Color coding for individual units as in Fig. 1 b.

sults of refraction experiments for the Moho and top limit of the lower crust (Majdański 2012) significantly reduced the number of possible solutions (Tab. 1). Based on the available data, the low density contrasts were assumed to be present within the Carpathian sedimentary succession. Since the Moho is practically flat in the study area, the pattern of gravity anomalies is influenced mostly by the crystalline basement configuration. The basement geometry and composition also control magnetic anomalies owing to negligible susceptibility of sedimentary rocks of the Carpathian units, the Paleozoic cover and the Miocene foredeep (Gnojek and Hubatka 2001). 


\subsection{Interpretation}

The main objective of the potential field study was to model the geometry of the Precambrian basement along the Carpathica 2018 cross-section. However, a qualitative analysis was carried out over a much larger area in order to investigate its broader structural context.

The obtained Bouguer anomaly values range from -58 to $+11 \mathrm{mGal}$ in the south and north, respectively (Fig. 5). There is a gradual southward increase of gravity force values, with positive anomalies aligned along the northern limit of the study area. The total horizontal derivative (THD) of the gravity data reveals ten structures, which are oriented in two dominant directions: (1) NE-SW in the western and southern parts of the area, and (2) W-E in its eastern part (Fig. 6). These features correspond to some structural elements that are shown on the geological map of the area (Figs 1 and 7). Lines marked as 1-4 (Figs 5-6) correlate perfectly with traces of the Carpathian thrust faults (Fig. 7). Consequently, the thrust planes have to represent the important density contrasts, and due to the shallow position, the associated gravity anomalies predominate over those related to the basement irregularities.

The Reduced-to-Pole (RTP) magnetic anomaly map clearly outlines the Bielsko-Biała magnetic low (B-B Low) (-78 nT) and Sól magnetic high (Sól High) (+65 nT) (Figs $5 \mathrm{~b}, 6 \mathrm{~b}$ ). These anomalies most probably represent lateral variations in the susceptibility of the basement rocks rather than basement depression or elevation. Such interpretation is suggested by the 2D modelling exercise described in the paragraph below and by previous studies carried out in the neighboring areas. The Sól magnetic high belongs to the South Moravian-Beskydy regional magnetic anomaly (Gnojek and Hubatka 2001) that continues beyond the Czech Republic into Poland and Slovakia. Several authors postulated a deep position of the basement in this area (Ryłko and Tomaś 1995; Paul et al. 1996a, b; Gnojek and Hubatka 2001; Buła and Habryn 2008).

Derivatives of the RTP magnetic data reveal some structures that might be rooted in the crystalline basement (Fig. 6). Structures related to the Sól High are oriented NE-SW, while those associated with the B-B Low encircle this feature (Figs $5 \mathrm{~b}$ and $6 \mathrm{~b}$ ). It seems that some structural elements interpreted from the magnetic data represent zones of maximum lateral susceptibility gradient rather than eventual basement faults. However, three of the interpreted faults (denoted A, B and C on Figs $5 \mathrm{~b}$ and $6 \mathrm{~b})$ appear in a 2D combined gravity and magnetic model that was built for the Carpathica 2018 section (Fig. 8). This suggests that they represent real basement faults.

The integrated quantitative analysis of gravimetric and magnetic data, including borehole and seismic data, resulted in a very small root mean error $(+2.4 \mathrm{nT}$ for magnetics and $0.41 \mathrm{mGal}$ for gravity data, Fig. 8 ). The gravity modelling process included the use of polygons determined based on surface and seismic data interpretation. Then, for each polygon, the density value was assigned corresponding to the particular rock type. The densities of rocks used for modelling (Tab. 1) were adopted from the literature (Grabowska et al. 2007; Bojdys et al. 2008) and the publicdomain density data from boreholes located close to the Carpathica 2018 section (Central Geological Database, http://geologia.pgi.gov.pl). The above-mentioned authors conducted a broad analysis of rock density for the Outer Carpathian units. Particularly Bojdys et al. (2008) presented the density spectrum along a profile parallel to, and located c. $40 \mathrm{~km}$ further $\mathrm{E}$ of, the Carpathica 2018 cross-section. For the Precambrian rocks, the density of $2.7 \mathrm{~g} / \mathrm{cm}^{3}$ was used, while for the lower crust and upper mantle, densities of $2.9-3.3 \mathrm{~g} / \mathrm{cm}^{3}$ were assumed. These values were adopted from the results of a seismic velocity and density modelling of Grad et al. (2006) and Malinowski et al. (2015). The Moho and the top of lower crust horizons were extracted from the grids compiled by Majdański (2012) based on the deep refraction sounding. The Moho is flat, smooth and lies at $36.5 \mathrm{~km}$ b.s.l., whereas the top of lower crust gradually descends from $26 \mathrm{~km}$ b.s.l. in the north, to $30 \mathrm{~km}$ b.s.l. in the south (Fig. 9). The model base is fixed at $70 \mathrm{~km}$ u.s.l.

Tab. 1 Color patterns for stratigraphic subdivisions used in geological models and values of density and susceptibility used in modelling

\begin{tabular}{|c|c|c|}
\hline Layer/block & Density $\left(\mathrm{g} / \mathrm{cm}^{3}\right)$ & Susceptibility (cgs) \\
\hline Magura Unit & 2.53 & 0 \\
\hline $\begin{array}{c}\text { Foremagura } \\
\text { Unit }\end{array}$ & 2.56 & 0 \\
\hline Dukla Unit & 2.58 & 0 \\
\hline $\begin{array}{l}\text { Silesian Unit } \\
\text { (Godula Unit) }\end{array}$ & 2.57 & 0 \\
\hline $\begin{array}{l}\text { Silesian Unit } \\
\text { (Cieszyn Unit) }\end{array}$ & 2.55 & 0 \\
\hline $\begin{array}{l}\text { Folded Miocene } \\
\text { complex }\end{array}$ & 2.45 & 0 \\
\hline $\begin{array}{c}\text { Miocene } \\
\text { (Foredeep) }\end{array}$ & 2.57 & 0 \\
\hline $\begin{array}{c}\text { Paleozoic cover } \\
\text { (Carboniferous/ } \\
\text { Devonian) }\end{array}$ & 2.49 & 0 \\
\hline $\begin{array}{l}\text { Precambrian } \\
\text { crystalline } \\
\text { basement }\end{array}$ & 2.7 & $0.01-0.015$ \\
\hline Lower Crust & 2.9 & 0 \\
\hline Upper Mantle & 3.3 & 0 \\
\hline
\end{tabular}



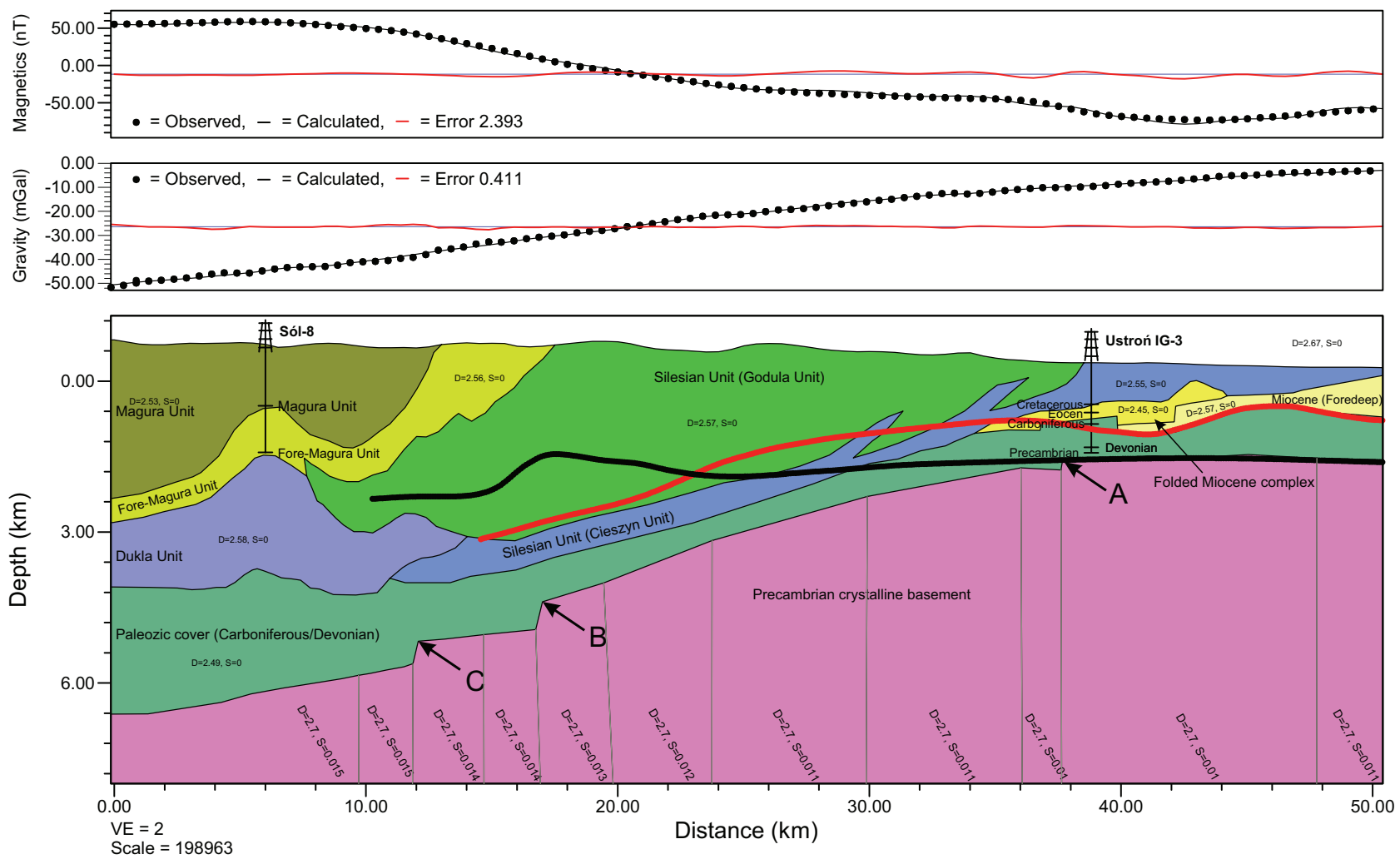

Fig. 8 Model Carpathica 2018. Upper part of the figure shows magnetic and gravity data. Dotted lines and solid black lines signify observed and modelled values, respectively. Red thin line denotes the magnitude of error. Lower part of the figure shows upper part of the geological model. The colors are shown in Tab. 1. Abbreviations: D - density in $\mathrm{g} / \mathrm{cm}^{3}, \mathrm{~S}$ - susceptibility in cgs units, VE - vertical exaggerations. Letters A, B and $\mathrm{C}$ indicate the same structures as on Fig. 5b and Fig. 6b. Red and black bold lines represent the top of the pre-Permian Paleozoic and Precambrian basement (Buła and Habryn 2008) and top of consolidated basement (Paul et al. 1996b), respectively.

(well below the Moho) and model layers extend to infinity in order to eliminate boundary effect on the edges of the model. Also, as the Carpathica 2018 cross-section runs orthogonal to the strike of first-order structural features, the gravity and magnetic effect of rock masses lying aside from the cross-section is believed to be negligible. The induced component was assumed as a main source of magnetization. This simplification was necessary as it is impossible to measure the remanent component in this case.

The gravity values gently increase northward along the profile from -52 to almost $-3 \mathrm{mGal}$, whereas the magnetic profile data present the reverse trend, thus decreasing from +55 to $-70 \mathrm{nT}$ (Fig. 8). The lateral changes in the magnetic susceptibility along the profile appear small and vary from 0.01 to 0.015 (cgs).

The 2D model shows the smooth top of the Precambrian crystalline basement gradually rising northward from 6700 to almost $1400 \mathrm{~m}$ b.s.l. Normal faults A, B and $\mathrm{C}$ are basement steps with vertical throws of $480 \mathrm{~m}$, $550 \mathrm{~m}$ and $300 \mathrm{~m}$, respectively. Furthermore, faults $\mathrm{C}$, $\mathrm{B}$ and $\mathrm{A}$ coincide with the position of the Magura, ForeMagura and Silesian frontal thrusts, respectively. This coincidence suggests significant basement control on the architecture of the allochthonous units.
Two basement horizons resulting from the earlier depth-to-basement studies are shown on the 2D model (Fig. 8). The thick black line represents the top of consolidated basement according to Paul et al. (1996b). To the north from the Ustron IG-3 well, in the area controlled by boreholes, previous interpretation nearly coincides with the Precambrian basement on the current model solution (Fig. 8). However, further south it is much shallower than the present solution. The thick red line shows the top of the pre-Permian Paleozoic according to Buła and Habryn (2008). This horizon corresponds well to the top of the Paleozoic sequence in the current model although it is somewhat too shallow in the central part of the profile. Both above-discussed horizons do not reach the southern end of the 2D model since the original maps (Paul et al. 1996b; Buła and Habryn 2008) do not cover the entire study area.

\section{Geological implications and discussion}

As stated in the introduction, the primary goal of the current study was to establish depth to the crystalline basement along the regional cross-section. 

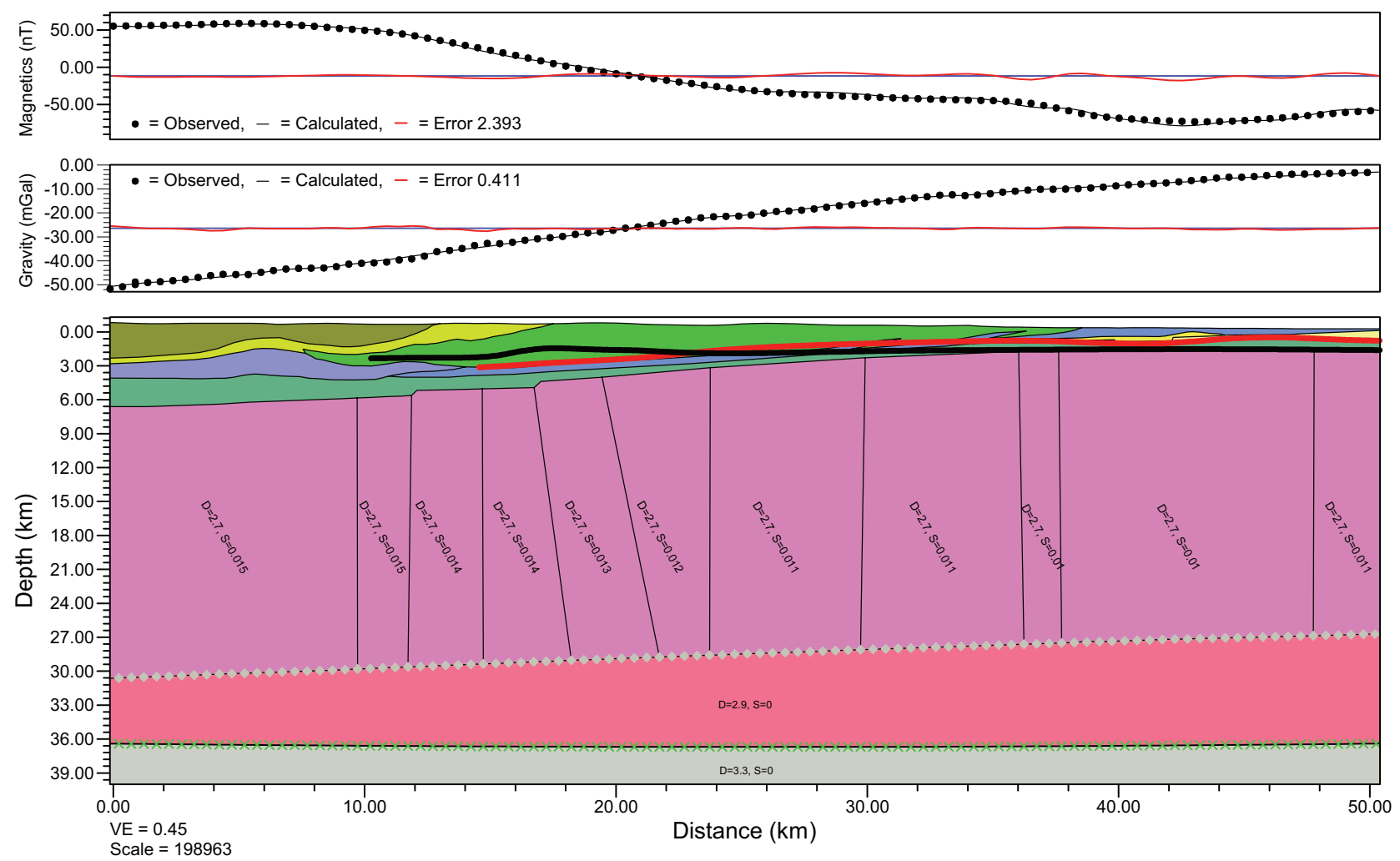

Fig. 9 Model Carpathica 2018. Upper part of the figure shows magnetic and gravity data. Dotted lines and solid black lines signify observed and modelled values, respectively. Red thin line denotes the magnitude of error. Lower part of the figure shows full geological model. The colors are shown in Tab. 1. Abbreviations: D - density in $\mathrm{g} / \mathrm{cm}^{3} ; \mathrm{S}$ - susceptibility in cgs units; VE - vertical exaggerations. Gray marks and green ' $\mathrm{X}$ ' signify the upper limit of the lower crust and Moho, respectively, derived from joint results of refraction surveys. Red and black bold lines represent the top of the pre-Permian Paleozoic and Precambrian basement (Buła and Habryn 2008) and top of consolidated basement (Paul et al. 1996b), respectively.

Our results clearly show that the top of the crystalline basement should be located much deeper than previously anticipated (Fig. 8) (Paul et al. 1996b; Buła and Habryn 2008). Our solution allows encompassing the whole sedimentary sequence of the Silesian Unit between the topographic surface and the top of the interpreted subCarpathian strata, which was impossible based on the previous interpretation (Fig. 8). In our opinion, the reasons for such inaccurate estimations of the basement depth and its cover thickness, presented by Paul et al. (1996a, b) and Buła and Habyn (2008), were related mainly to the lack of constrains (e.g. wells or seismic data) in the southern part of the Silesian Unit. Paul et al. (1996b) used only the magnetotelluric data to determine the depth and the basement structure. It the northern part of the profile, where numerous wells reached the crystalline rocks, the results of Paul et al. (1996b) fit our solution. However, in the southern part of the Silesian Unit, where the inversion of the magnetotelluric data was unconstrained, the solution may be uncertain. Moreover, as stated by Ryłko and Tomaś (1995), the high resistivity horizon visible in the magnetotelluric data was interpreted as the top of the crystalline basement. In our opinion, it cannot be ruled out that high resistivity horizons exist within the Carpathian flysch or the Paleozoic cover (Stefaniuk 2006). If so, they may be easily misinterpreted as the crystalline basement. On the other hand, upper limit of the Paleozoic and Precambrian strata presented by Buła and Habryn (2008) differs mainly in terms of depth, while its shape is comparable to our results (Fig. 8). An application of lower densities for the Silesian Unit during the 2D gravity modelling would shift the basement to lower depths and produce results comparable to the solution of Buła and Habryn (2008). Such an approach, even though theoretically possible, would require geologically unrealistic densities.

In both discussed cases it seems very likely that the authors did not consider the thickness of the Silesian Unit as an important input during the depth to the basement estimation. What also speaks in favor of our interpretation is the fact that in the southernmost part of the Carpathica 2018 cross-section the base of the Carpathian units was firmly constrained by the seismic data. This information was unavailable to the previous authors.

Two-dimensional gravity modelling also allowed us to identify a relatively thin layer of the basement sedimentary cover (most likely represented by the Devonian and Carboniferous sediments) along the entire cross-section. 
While the presence of the Paleozoic strata in the north is proven by numerous wells (e.g.: Ustroń C-1, Ustroń IG-2 and Ustron U-3A) and in the southernmost part might be inferred from the seismic data, their presence in the center is in disagreement with the previously published maps (Picha et al. 2006; Buła and Habryn 2008). Due to the insufficient accuracy of the gravity and magnetic data and their non-unique solution, it is not possible to unequivocally identify this body as the Devonian and Carboniferous strata. However, almost all deep wells drilled in the Czech Republic in the vicinity of the Polish border encountered the Paleozoic strata below the Carpathians Fold and Thrust Belt (Fig. 1). On the other hand, the Bystra-IG1 well located to the east (Fig. 1), reached the basement directly below the Carpathian units. Thus, despite the fact that our interpretation favors the presence of a continuous Paleozoic cover along the entire crosssection, we are aware of its uncertainty. Alternatively, the Paleozoic complex might be replaced by the Miocene sequence, or possibly, thicker than estimated, lowermost part of the lithostratigraphic profile of the Silesian Unit (the Vendryně Fm.?).

Although the qualitative interpretation of the gravity and magnetic maps was initially performed only to support the $2 \mathrm{D}$ quantitative interpretation, it has helped to recognize some distinct features of the crystalline basement. The Bouguer anomaly gravity map, portraying the general structural character of the basement, suggests rather simple south-dipping morphology (Fig. 5). The gravity THD map clearly shows a zone corresponding to the Żywiec tectonic window (Fig. 6a). The gravity data indicate that the crystalline basement within this zone is much deeper than in the surrounding area (Fig. 5a). Taking into consideration that the Subsilesian Unit crops out within the Żywiec tectonic window, which is located below the Silesian Unit, an elevated basement was rather expected. To resolve this contradiction, a thick layer of Carboniferous and Devonian sedimentary rocks is presumed. Other distinct features interpreted from the gravity data are the lineaments which belong to two groups. The first group exhibits WSW-ENE trend and is representative of the western part, while the second one, with almost latitudinal strike, occurs to the east of the Żywiec tectonic window. This might suggest that this window forms a part of a broader tectonic zone that probably juxtaposes two separate basement blocks of different structural characteristics. Also the small tectonic window located between Skoczów and Ustron is bound by lineaments detected by gravity and magnetic methods (Figs 6-7). This supports the idea that the basement structure influenced the evolution of the OCFTB.

The magnetic map reveals also a strong positive anomaly located directly below the Sól-8 borehole (Fig. 5b).
As our interpretation suggests rather deep basement position in this part of the OCFTB, the anomaly should be linked with the changes in the magnetic susceptibility of the basement rocks, which most probably constitute an extension of the positive anomaly identified in the Czech Republic and related to the intermediate and basic rocks (Gnojek and Hubatka 2001).

The second characteristic feature is a negative anomaly (the Bielsko-Biała Low) located in the central part of the research area (Fig. 5b). Its outline can be precisely traced on the magnetic THD maps (Fig. 6b). Currently, no probable explanation of the origin of this structure is available.

It was also observed that, except for the area of the frontal thrust of the Magura and Fore Magura units, the lineaments detected based on the gravity and magnetic data analysis do not coincide with each other. Our interpretation is that, due to the low magnetic susceptibility contrast within the sedimentary units, lineaments detected on magnetic maps represent solely the basement-rooted structural features, while the gravity-detected lineaments might have originated in both the Carpathian units and the crystalline basement. The structures interpreted on the gravity THD maps in the Magura and Fore Magura thrust zone are believed to reflect superposition of the gravity effects from the deep rooted faults, visible on the magnetic THD map, and the shallow structures.

\section{Conclusions}

The main objective of this project was to determine the structure and the depth of the crystalline basement along the regional cross-section that stretches SE-NW in the westernmost part of the Polish Outer Carpathians. In our approach, we used seismic data, well information and surface observations to establish the structure of the Carpathian Orogen along the regional cross-section, which provides the main input for the $2 \mathrm{D}$ potential field modelling. The modelling allowed to upgrade the initial cross-section, which currently encompasses both the Carpathian units and their substratum. Additionally we used gravity and magnetic maps and their derivatives to identify possible fault zones within the crystalline basement.

The most important finding from our work is that the assumption of a deeper position of the crystalline basement has been proven. We also identified a continuous sedimentary layer sandwiched between the Carpathian units and the crystalline basement. In our opinion, this layer should be regarded as the Devonian-Carboniferous sedimentary cover. However, other possibilities, such as the Miocene foredeep deposits, should be also taken into account. The gravity and magnetic maps, as well as their derivatives, suggest a complicated structure of 
the basement in terms of tectonics and lithologies. The origin of some of the anomalies (e.g. the Sól High) can be plausibly explained by higher magnetic susceptibility of the intermediate and basic basement rock units, while the origin of other anomalies, such as the Bielsko-Biała Low, remains unknown.

Acknowledgments: The presented study results were partially obtained within the framework of the research project Blue Gas (BG2/ShaleCarp/14), financed by the National Centre for Research and Development (NCBiR). J. Barmuta and K. Starzec were financially supported by Departments' Statutory Works. Additionally, J. Barmuta was also financed by the Dean's Grant no. 15.11.140.182. M. Mikołajczak acknowledges financial support from the Polish National Science Centre grant UMO-2017/25/B/ ST10/01348. For the regional cross-section construction the authors acknowledge the use of the Move Software Suite granted by the Petroleum Experts Ltd. Stanisław Mazur is thanked for his valuable comments and suggestions. Nils Holzrichter and an Anonymous Reviewer are thanked for their constructive comments and suggestions. Special thanks to the editors Alexandra Guy and Vojtěch Janoušek for their support and suggestions helping to improve the manuscript version of the paper.

\section{References}

BoJdys G, LEMBERGER M (1986) Three-dimensional gravity modeling of Earth's crust and upper mantle in the Polish Carpathians. Ann Soc Geol Pol 53: 349-373

Bojdys G, Grabowska T, Medoń Z (2008) Two dimensional gravity modelling in Polish Western Carpathians. Geologia 34: 147-170

BuŁa Z, Habryn R (2008) Geological-structural atlas of the Palaeozoic basement of the Outer Carpathians and Carpathian foredeep. Państwowy Instytut Geologiczny, Warsaw, pp 1-74 (in Polish)

BuŁA Z, ŻABA J (2008) Structure of the Precambrian basement of the eastern part of the Upper Silesian block (Brunovistulicum). Przegl Geol 56: 473-480

BuŁa Z, Habryn R, Jachowicz-ZdanowsKa M, ŻABA J (2014) The Precambrian and Lower Paleozoic of the Brunovistulicum (eastern part of the Upper Silesian Block, southern Poland) - the state of the art. Geol Q 59: 123-134

Burtan J (1973) Detailed Geological Map of Poland, 1 : 50 000, Wisła sheet. Wydawnictwa Geologiczne, Warsaw

Central Geological Database (CBDG). Accessed on January, 2019, at http://geologia.pgi.gov.pl/

Cieszkowski M, Golonka J, WaśKowska-Oliwa A, Chodyń R (2007) Type locality of the Mutne Sandstone Member of the Jaworzynka Fm., Western Outer Carpathians, Poland. Ann Soc Geol Pol 77: 269-290
Cocks LRM (2002) Key Lower Palaeozoic faunas from near the Trans-European Suture Zone. In: Winchester JA, Pharaoh TC, Verniers J (eds) Palaeozoic Amalgamation of Central Europe. Geological Society of London Special Publications 201: 37-46

Cocks LRM, TorsviK TH (2005) Baltica from the late Precambrian to mid-Palaeozoic times: the gain and loss of a terrane's identity. Earth Sci Rev 72: 39-66

GaWęDa A, Golonka J (2011) Variscan plate dynamics in the circum-Carpathian area. Geodin Acta 24: 141-155

GNOJEK I, HuBATKA F (2001) Structure of the Brunovistulian Unit (E part of the Czech Republic) on the basis of seismic and magnetic data. Bull Czech Geol Surv 76: 157-168

Golonka J (2007a) Phanerozoic paleoenvironment and paleolithofacies maps. Early Paleozoic. Geologia 35: 589-654

Golonka J (2007b) Tectonics of the Polish Flysh Carpathians between Bielsko-Biała and Nowy Targ. Geologia 33: 29-38 (in Polish with English summary)

Golonka J, WaśKowska A (2012) The Beloveža Formation of the Rača Unit in the Beskid Niski Mts. (Magura Nappe, Polish Flysch Carpathians) and adjacent parts of Slovakia and their equivalents in the western part of the Magura Nappe; remarks on the Beloveža- Hieroglyphic Beds controversy. Geol Q 56: 821-832

Golonka J, Gahagan L, Krobicki M, Marko F, OszcZYPKO N, ŚlĄCZKA A (2006) Plate-tectonic evolution and paleogeography of the circum-Carpathian region. In: Golonka J, Picha FJ (eds) The Carpathians and their Foreland: Geology and Hydrocarbon Resources. AAPG Memoir 84: 11-46

Golonka J, Krobicki M, Poprawa P, Paul Z, Khudoley A (2009a) Early Paleozoic evolution of the peri-Gondwana plates. Geologia 35: 339-343

Golonka J, Pietsch K, Marzec P, Stefaniuk M, WAŚKowska A, CIESZKOWski M (2009b) Tectonics of the western part of the Polish Outer Carpathians. Geodin Acta 22: 81-97

Golonka J, Pietsch K, Marzec P (2011) Structure and plate tectonic evolution of the northern Outer Carpathians. In: Closson D (ed) Tectonics. InTech, Rijeka, 65-92

GóRECKI W (2011) Atlas of Geothermal Waters and Energy Resources in the Western Carpathians. AGH -University of Science and Technology, Cracow, pp 1-772

Grabowska T, Bojdys G, Lemberger M, Medoń Z (2007) Geophysical-and-geological interpretation of gravity and magnetic anomalies in Polish Western Carpathians. Geologia 33: 103-126

Grad M, Guterch A, Keller GR, Janik T, Hegedus E, Vozar J, Ślączka A, TiIra T, Yliniemi J (2006) Lithospheric structure beneath trans-Carpathian transect from Precambrian platform to Pannonian Basin: CELEBRATION 2000 seismic profile CEL05. J Geophys Res 111(B3): 1-23 
Grauch V, Cordell L (1987) Limitations of determining density or magnetic boundaries from the horizontal gradient of gravity or pseudogravity data. Geophysics 52: 118-121

Heflik W, Konior K (1974) The present state of knowledge concerning the crystalline basement in the CieszynRzeszotary area. Biul Inst Geol 273: 195-228 (in Polish with English summary)

Heflik W, Moryc W (1996) The crystalline basement in the borehole Krasna-1 near Cieszyn. Bull Pol Acad Sci, Earth Sci 44: 37-50

Kadima E, Delvaux D, Sebagenzi SN, Tack L, Kabeya SM (2011) Structure and geological history of the Congo Basin: an integrated interpretation of gravity, magnetic and reflection seismic data. Basin Res 23: 499-527

Kalvoda J, Bábek O, Fatka O, Leichmann J, MeliChar R, Nehyba S, ŠpačeK P (2008) Brunovistulian Terrane (Bohemian Massif, Central Europe) from late Proterozoic to late Paleozoic: a review. Geol Rundsch 97: 497-518

Konior K, ToKARski A (1959) New deep key borehole south of Cieszyn. Biul Inst Geol 140 (in Polish with English summary)

Kotas A (1994) Coal-bed methane potential of the Upper Silesian Coal Basin, Poland. Pr Państw Inst Geol 142: $1-81$

Koszarski L, Sikora W, Wdowiarz S (1974) The Flysch Carpathians. Polish Carpathians. In: MAHEL M (ed) Tectonic of the Carpathian-Balkan Regions. GÚDŠ, Bratislava, pp 180-197

Królikowski Cz, MŁynarski S (2003) Deep basement structure of the Polish Carpathians based on the integrated interpretation of geophysical data. Geologia 29: 197-218

KsIĄŻKIEWICZ M (1966) Geology of the Babia Góra region. Przewodnik XXXIX Zjazdu PTG, Babia Góra, 36: 5-59 (in Polish)

KSIĄŻKIEWICZ M (1974) Detailed Geological Map of Poland, 1:50 000, Sucha Beskidzka sheet. Wydawnictwa Geologiczne, Warsaw (in Polish)

MacLeOd IN, Jones K, DA TF (1993) 3-D analytic signal in the interpretation of total magnetic field data at low magnetic latitudes. Explor Geophys 24: 679-691

MAJDAŃSKI M (2012) The structure of the crust in TESZ area by kriging interpolation. Acta Geophys 60: 59-75

Malata E, Malata T, OszczypKo N (1996) Litho- and biostratigraphy of the Magura Nappe in the Eastern part of the Beskid Wyspowy Range (Polish Western Carpathians). Ann Soc Geol Pol 66: 269-284

Malinowski M, Żelaźniewicz A, Grad M, Guterch A, JANIK T (2005) Seismic and geological structure of the crust in the transition from Baltica to Palaeozoic Europe in SE Poland - CELEBRATION 2000 experiment, profile CEL02. Tectonophysics 401: 55-77
Malinowski M, Guterch A, Narkiewicz M, Petecki Z, Janik T, Środa P, Maksym A, Probulski J, Grad G, Czuba W, GaCzyński E, MaJdański M, JANKOWsKi L (2015) Geophysical constrains on the crustal structure of the East European Platform margin and its foreland based on the POLCRUST-01 deep reflection profile. Tectonophysics 653: 109-126

MoczydŁowska M (1997) Proterozoic and Cambrian successions in Upper Silesia: an Avalonian terrane in Southern Poland. Geol Mag 134: 679-689

MORYC W (2005) Development of research on Western Carpathian Miocene deposits in the Bielsko-Kraków area. Geologia 43: 5-73 (in Polish with English summary)

MoryC W, HeFliK W (1998) Metamorphic rocks in the basement of the Carpathians between Bielsko-Biała and Cracow. Geol Q 42: 1-14

Nawrocki J, Poprawa P (2006) Development of TransEuropean Suture Zone in Poland: from Ediacaran rifting to Early Palaeozoic accretion. Geol Q 50: 59-76

NAWrocki J, ŻylińsKa A, BuŁa Z, GrabowsKi J, KrZYWIEC P, POPRAWA P (2004) Early Cambrian location and affinities of the Brunovistulian Terrane (Central Europe) in the light of palaeomagnetic data. J Geol Soc, London 161: 513-522

NARKIEWICZ M (2007) Development and inversion of Devonian and Carboniferous basins in the eastern part of the Variscan foreland (Poland). Geol Q 51: 231-256

NeMČoK M, KRZYWiec P, WojtaszeK M, Ludhová L, Klecker RA, Sercombe W, Coward MP (2006) Tertiary development of the Polish and eastern Slovak parts of the Carpathian accretionary wedge: insight from balanced cross-sections. Geol Carpath 57: 355-370

NemČok M, Sinha ST, Stuart CJ, Welker C, Choudhuri M, Sharma SP, Misra AA, Sinha N, Venkatraman S (2013) East Indian margin evolution and crustal architecture: integration of deep reflection seismic interpretation and gravity modelling. In: MOHRIAK WU, DANFORTH A, Post PJ, Brown DE, Tari GC, Nemčok M, Sinha ST (eds) Conjugate Divergent Margins. Geological Society of London Special Publications 369: 477-496

Nescieruk P, Wóscik A (2001a) Detailed Geological Map of Poland, 1 : 50 000, Wisła sheet. Wydawnictwa Geologiczne, Warsaw

Nescieruk P, Wójcik A (2001b) Detailed Geological Map of Poland, 1 : 50 000, Skoczów sheet. Wydawnictwa Geologiczne, Warsaw

OszczypKo N (1992) Late Cretaceous through Paleogene evolution of the Magura Basin. Geol Carpath 46: 33-338

OszczypKo N (2004) The structural position and tectonosedimentary evolution of the Polish Outer Carpathians. Przegl Geol 52: 780-779

OszczypKo N, DudziaK JK, MaLATA E (1990) Stratigraphy of the Cretaceous through Palaeogene deposits of the Magura Nappe in the Beskid Sądecki Range, Polish Outer Carpathians. Stud Geol Polon 97: 109-181 
Oszczypko N, Malata E, BąK K, KęDzierski M, OszCZYPKO-CLOWES M (2005) Lithostratigraphy and biostratigraphy of the Upper Albian-Lower/Middle Eocene flysch deposits in the Bystrica and Rača subunits of the Magura Nappe; Western Flysch Carpathians (Beskid Wyspowy and Gorce Ranges, Poland). Ann Soc Geol Pol 75: 27-69

Paul Z, RyŁko W, Tomaś A (1996a) Geological structure of the western part of the Polish Carpathians. Geol Q 40: 501-520

PAul Z, RyŁko W, Tomaś A (1996b) Influence of tectonic of the consolidated basement of the Carpathians on distribution of flysch masses in the Polish part of the Western Carpathians. Geol Q 40: 487-500

PICHA FJ, STRÁNÍK Z, KREJČí O (2006) Geology and hydrocarbon resources of the Outer Western Carpathians and their foreland, Czech Republic. In: Golonka J, PicHA FJ (eds) The Carpathians and their Foreland: Geology and Hydrocarbon Resources. AAPG Memoir 84: 49-175

RipPIngton S, Mazur S, WARner J (2015) The crustal architecture of the Faroe-Shetland Basin: insights from a newly merged gravity and magnetic dataset. In: RicHARDS F, Richardson N, RipPINGTON S, WiLsON W (eds) Industrial Structural Geology: Principles, Techniques and Integration. Geological Society of London Special Publications 421: 169-196

RYŁKo W, Tomaś A (1995) Morphology of the consolidated basement of the Polish Carpathians in the light of magnetotelluric data. Geol Q 39: 1-16

RYŁKo W, ŻYTKO K (1980) Directions of hydrocarbon exploration in the flysch deposits of the Western Carpathians based on results of previous studies. Prz Geol 28: 547-551 (in Polish)

RyŁko W, Żyтко K, RĄczKowski W, Wóscik A (1992) Detailed Geological Map of Poland, 1:50 000, Czadca-Ujsoły sheet. Wydawnictwa Geologiczne, Warsaw

Sikora W, ŻyTKo K (1960) Geology of the Beskid Wysoki Range south of Żywiec (Western Carpathians). T. IV. Biul Inst Geol 141: 61-204 (in Polish with English summary)

SŁomka T, SŁomka E (2001) Sequences of the lithofacies and depositional intervals in the Godula Beds of the Polish Outer Carpathians. Ann Soc Geol Pol 71: 35-42

StAmPfli GM, KozUr HW (2006) Europe from the Variscan to the Alpine cycles. In: GEE DG, STEPHENSON RA (eds) European Lithosphere Dynamics. Geological Society of London, Memoirs 32: 57-82

Starzec K, Schnabel W, Szotek A, Pastucha M (2014) Updating of the surface geological map in frame of the project "Seismic data acquisition Sól 2D". Unpublished map, Geokrak Company, Cracow

Starzec K, Barmuta J, Stefaniuk M (2017) The structure of the Silesian and Magura units in the westernmost Polish Outer Carpathians. In: $17^{\text {th }}$ International Multidisci- plinary Scientific Geoconference SGEM 2017, Vienna. GREEN Conference Proceedings 17: 477-484

STEFANIUK M (2006) Some results of a new magnetotelluric survey in the area of the Polish Outer Carpathians. In: Golonka J, Picha FJ (eds) The Carpathians and their Foreland: Geology and Hydrocarbon Resources. AAPG Memoir 84: 707-716

STEFANiUK M, KLITYŃSKi W, JARZYNA J, GOLONKA J (2007) The structure of the Carpathian overthrust and its basement in the Polish Western Carpathians in the light of reinterpretation of selected regional magnetotelluric profiles. Geologia 33: 143-166

ŚlączKa A, Kruglov S, Golonka J, OszczypKo N, PoPADYUK I (2006) Geology and hydrocarbon resources of the Outer Carpathians, Poland, Slovakia, and Ukraine: general geology. In: GolonkA J, PicHA FJ (eds) The Carpathians and their Foreland: Geology and Hydrocarbon Resources. AAPG Memoir 84: 221-258

TALWANi M (1965) Computation with the help of a digital computer of magnetic anomalies caused by bodies of arbitrary shape. Geophysics 30: 797-817

TALWANi M, EWIng M (1960) Rapid computation of gravitational attraction of three-dimensional bodies of arbitrary shape. Geophysics 25: 203-225

TALWAni M, HeIRTZLER JR (1964) Computation of magnetic anomalies caused by two-dimensional structures of arbitrary shape. In: PARKS GA (ed) Computers in the mineral industries. Part 1. Stanford Uni Publ, Geol Sci 9: 464-480

TAlWAni M, Worzel LJ, LANDisman M (1959) Rapid gravity computations for two-dimensional bodies with application to the Mendocino submarine fracture zone. J Geophys Res 64: 49-59

Wójcik A, NescieruK P (2000) Detailed Geological Map of Poland, 1:50 000, Pszczyna sheet. Wydawnictwa Geologiczne, Warsaw

Wójcik A, SzydŁo A, Marciniec P, Nescieruk P (1999) Folded Miocene of the Andrychów region - new tectonic unit. Prace PIG 168: 231-248 (in Polish with English summary)

ŻELAŹNIEWICZ A, AlEKSANDrowsKi P, BuŁa Z, KARNKOWSKI PH, Konon A, OszczypKo A, ŻABA J, ŻYTKo K (2011) Tectonic subdivision of Poland. Komitet Nauk Geologicznych PAN, Wrocław. pp 1-60

ŻyTKo K (1978) Data of Bystra IG-1 exploration borehole (Western Carpathians). Kwart Geol 4: 943-945 (In Polish)

ŻytKo K, ZająC R, Gusik S, RyŁko W, OszczypKo N, Garlicka I, NemČoK J, Eliáš M, MenčIK E, Stráník Z (1989) Map of the tectonic elements of the Western Outer Carpathians and their foreland. In: POPRAWA D, NEMČOK $\mathrm{J}$ (eds) Geological Atlas of the Western Carpathians and their Foreland. Państwowy Instytut Geologiczny, Warsaw/ GÚDŠ Bratislava/ÚÚG Prague 